\title{
DIVERSITY AND VERTICAL DISTRIBUTION OF VASCULAR EPIPHYTES ON A MALAYSIAN MANGROVE ISLAND**
}

\author{
SHAHRUDIN ROHANI*, FEI LIN LEE AND ABDUL SHUKOR YUSOFF \\ Faculty Science and Marine Environment, Universiti Malaysia Terengganu, 21030 Kuala Nerus, Malaysia
}

Received 01 January 2019 / Accepted 07 February 2019

\begin{abstract}
Many studies have attempted to explain the diversity and abundance of epiphytic plants in major ecosystems, worldwide. However, investigations on the abundance of epiphytic plants in mangroves have remained rare. The aim of this research was to study the diversity and vertical distribution of vascular epiphytes in a mangrove forest in peninsular Malaysia. The sampling was done over a 0.1 hectare of Pulau Telaga Tujuh, a mangrove island in Terengganu, Malaysia. Trees with vascular epiphytes were divided into three strata: basal, trunk and canopy. The vascular epiphytes were identified, and the number of individuals in each stratum was recorded. In total, 8 species of vascular epiphytes from 6 genera and 4 families were recorded. Pulau Telaga Tujuh mangrove forest exhibited a relatively low diversity of vascular epiphytes $\left(H^{\prime}=1.43\right)$. The dominance of Hydnopytum formicarum significantly contributed to the diversity of vascular epiphytes in this forest. The highest abundance of epiphytes was observed on the trunks of the host trees. The vertical distribution pattern observed in this study is associated with the adaptation of the epiphytic plants to stresses in the mangrove ecosystem, particularly, drought and salt spray. Pulau Telaga Tujuh had a high density of vascular epiphytes but lower diversity compared with other ecosystems.
\end{abstract}

Keywords: epiphyte ecology, mangroves, Setiu Wetlands, spatial distribution

\section{INTRODUCTION}

Epiphytes are plants that germinate and live on trees without taking nutrients from the soil or the host tree. Vascular epiphytes such as orchids and ferns are able to adapt to an aerial environment, resulting in their morphological variations. Diversity of vascular epiphytes cannot be overemphasized as it contributes to vascular plants diversity constituting roughly $9 \%$ of all the vascular plants (Zotz 2013). Since the $18^{\text {th }}$ century, studies of vascular epiphytes have been conducted around the world, particularly in tropical regions known for their rich biodiversity (Zotz 2016).

Vascular epiphyte diversity plays an important role in forest ecosystems especially of those epiphytes living in the canopy zones as these plants help to regulate the cycling of nutrients (Coxson \& Nadkarni 1995). Dead

\footnotetext{
${ }^{*}$ Corresponding author, e-mail: rohanishahrudin@umt.edu.my

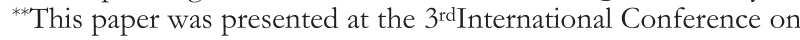
Tropical Biology 2018, 20-21 September 2018, Bogor, West Java, Indonesia
}

vascular epiphytes decompose and create organic matter on the ground or form humus on tree branches or trunks (Coxson \& Nadkarni 1995). This organic matter provides nutrients and increases the biomass of the ground, especially in primary forest (Nadkarni et al. 2004). Vascular epiphytes also provide a variety of food resources for many organisms such as birds and insects. For example, 59\% of 33 species of birds in a tropical rain forest in Costa Rica were observed foraging epiphytes resources (Nadkarni \& Matelson 1989). Some epiphytes exhibit a positive association with ants. Ants help to disperse seeds for epiphytes, and the plants provide a nest for the ants (Kaufmann et al. 2001; Dejean et al. 2003).

The distribution of vascular epiphytes tends to be affected by the availability of substrate and the distance of dispersal of seeds rather than the mode of dispersal (Nieder et al. 2000). The microhabitat (e.g., light intensity, proximity to soil or exposure to wind and precipitation) is associated with the availability of substrate and therefore, influence species richness and the 
abundance of vascular epiphytes in each stratum and host trees (Quaresma \& Jardin 2014; Woods et al. 2015; Getaneh \& Gamo 2016; Wang et al. 2016). Vascular epiphytes also tended to colonize zones with similar microhabitats indicating that vascular epiphytes may be specific to a particular strata (Woods 2013). Strata specificity shed light on the pattern of vertical distribution of vascular epiphytes (Kersten et al. 2009).

The tendency of epiphytes to occupy a similar microhabitat can also stem out from their resource-utilizing mechanisms. Since major portion of epiphytes do not attach to the soil, epiphytes show several strategies to obtain nutrients and water supply from their microenvironment (Benzing 1990). Epiphytes get nutrients from internal and external inputs; internally from leaves leachate from host-tree and nitrogen fixing bacteria (Hietz et al. 2002) and externally through dry deposition and precipitation (Fürnkranz et al. 2008; Zotz 2016). Epiphytes also receive nutrients input from throughfalls and stemflow (Awasthi et al. 1995; Chuyong et al. 2004). Moreover, different epiphytes use different nutrient uptake mechanisms, hence, the co-occurrence of different assemblage of epiphytes (Cardelús \& Mack 2010).

To adapt to drought environment in the canopy, epiphytes developed morphological adaptations such as succulent leaves and water absorbing structures (Benzing 1990; Hietz et al. 1999). Physiological adaptation such as Crassulacean Acid Metabolism (CAM) photosynthesis also occurs among many epiphytes (Silvera et al. 2010). CAM photosynthetic plants, like many epiphytes, open their stomata during night time to capture $\mathrm{CO}_{2}$ and close the stomata during daylight.

Many studies have focused on documenting the richness of mangrove flora yet, little attention has been given to epiphytic plants in this forest type. Epiphytes are perhaps the most susceptible to mangrove destruction because they depend on having large trees as their hosts. Recently, the epiphyte Hydnophytum formicarum was found to be remarkably abundant in Pulau Telaga Tujuh, Malaysia (Rohani et al. 2017). This finding motivated the authors to investigate the occurrence of other vascular epiphytes on the island. Hence, this study aimed to determine the species diversity and vertical distribution of vascular epiphytes in a mangrove ecosystem in the Setiu Wetlands in the east coast of peninsular Malaysia.

\section{MATERIALS AND METHODS}

\section{Study Site}

The research was conducted in Pulau Telaga Tujuh, Setiu Wetlands, Terengganu, Malaysia $\left(05^{\circ} 41.800^{\prime} \mathrm{N} ; 1^{\circ} 41.770^{\prime}\right.$ E). The Setiu Wetlands is an ecosystem with nine interconnecting habitats of beach, sea, mudflat, fresh and brackish water, river, islands, coastal and mangrove forests (Jamilah et al. 2015). This unique ecosystem, gazetted as state park in May 2018, support a myriad of biodiversity and are equally important to local people's livelihoods. The study site was one of the small islets in the Setiu Lagoon ( $5.42 \mathrm{ha}$ ), situated side by side with 13 other islands.

\section{Data Collection}

Ten plots of $10 \mathrm{~m}^{2}$ each $\left(1,000 \mathrm{~m}^{2}\right.$ in total $)$ were randomly established along the island. Every tree in each subplot was inspected for the occurrence of vascular epiphytes. The abundance of all vascular epiphytes, the strata and the host characteristics (e.g., stem diameter and height) were recorded. The host's strata were classified into three: 1) canopy - first branch to the tip of the tree; 2) trunk - $1.3 \mathrm{~m}$ above the ground to the first branch; and 3) basal - ground up to $1.3 \mathrm{~m}$ high in the host tree. For trees with an enlarged stem the base was 1.3 $m$ above the ground (Getaneh \& Gamo 2016).

All of the vascular epiphytes were included in the census except for the seedlings that were difficult to identify up to the species level. The epiphytes that grew in clusters that were difficult to count individually were counted as an independent individual (Getaneh \& Gamo 2016). Binoculars were used to observe the epiphytes that were located high in the trees. The names of the epiphyte species and host plants were referred to A Catalogue of the Vascular Plants of Malaya (Turner 1995). Voucher specimens were deposited at the Universiti Malaysia Terengganu Herbarium (UMTP). 


\section{Data Analysis}

Vascular epiphyte diversity was analyzed using two diversity indices; Shannon diversity index $\left(\mathrm{H}^{\prime}\right)$ and Simpson's index (D) (Magurran \& McGill 2011). To check the similarity between the epiphyte communities of each host tree, a Cluster analysis was carried out using the Jaccard similarity index based on the number of individuals of each vascular epiphyte species on each host tree. The data were analyzed using PAST version 3.15 software (Hammer et al. 2001).

\section{RESULTS AND DISCUSSION}

\section{Species Diversity}

A total of 929 individuals belonging to 8 species, 6 genera and 4 families were recorded in this study (Table 1) (Fig. 1). The density of vascular epiphytes in the plots was, on average, 0.93 individuals $/ \mathrm{m}^{2}$. The Shannon diversity index of this plant was low $\left(\mathrm{H}^{\prime}=1.43\right)$. Meanwhile, the Simpson's index (D) was 0.31, indicating the dominance of one species in the species richness. Mangrove forests in Southeast Asia exhibit at least 28 species of epiphytic plants (Giesen et al. 2007). In other words, $28.6 \%$ of mangrove epiphytic species can be found in Pulau Telaga Tujuh. In comparison, an earlier epiphytic study in a Malaysian mangrove forest found 16 species from 8 families (Japar Sidik et al. 2001).

Apocynaceae, with 3 species, was the wellrepresented family in terms of species number. Hydnophytum formicarum was the species with the largest number of individuals in the study site. In many previous studies on epiphytes, species with dust-like seeds have been found to be dominant. Orchidaceae was recorded as the dominant epiphyte family in the natural forests as well as in rubber plantations in Malaysia (Kiew \& Anthonysamy 1987). Most species from Orchidaceae have small seeds which facilitated their dispersal by wind.

The rank-abundance curve (Fig. 3) revealed an unequal proportion of common species and rare species. The steep line in the graph was derived from the dominance of Hydnopbytum formicarum. This plant, which has a close association with ants (hence sometimes called the "ant plant"), was also reported as a common species and more abundant than other non-antassociated species in Ulu Endau, Johor, Malaysia (Kiew \& Anthonysamy 1987). A high abundance of ant-associated epiphytic species was also found in the Amazonian lowland rainforest (Nieder et al. 2000). This high abundance of the ant plants in one ecosystem may be due to the ants helping to cultivate the seeds. This phenomenon, called ant farming, was proposed by Chomicki and Renner (2016) after their observation of the evolutionary history between ants and epiphytic plants. The ants collected the seeds and deposited these in the bark fissures, where the seeds germinated. This situation might also have occurred in Hydnophytum formicarum in Pulau Telaga Tujuh as their individuals were distributed in a clumped pattern (Rohani et al. 2017).

Table 1 List of vascular epiphytes in Pulau Telaga Tujuh, Terengganu, Malaysia

\begin{tabular}{llc}
\hline Species & Family & Number of individuals \\
\hline Dendrobium crumenatum & Orchidaceae & 8 \\
Dischidia nummularia & Apocynaceae & 150 \\
Hoya coronaria & Apocynaceae & 51 \\
Hoya verticillata & Apocynaceae & 5 \\
Hydnophytum formicarum & Rubiaceae & 462 \\
Pyrrosia piloselloides & Polypodiaceae & 127 \\
Taeniophyllum glandulosum & Orchidaceae & 125 \\
Dendrobium sp. & Orchidaceae & 1 \\
\hline
\end{tabular}



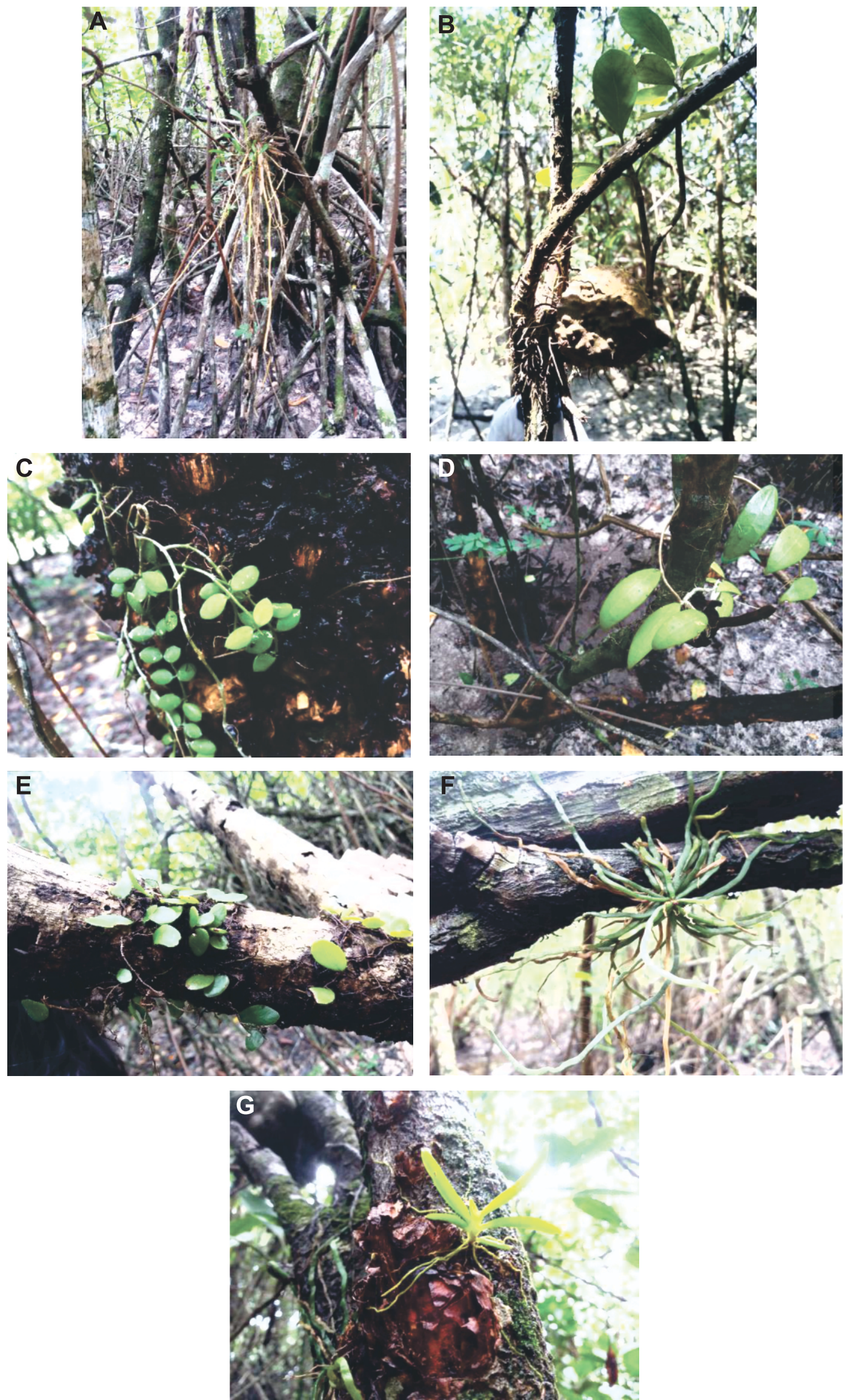

Figure 2 Photos of vascular epiphytes found in Pulau Telaga Tujuh, Terangganu

Notes: $\mathrm{A}=$ Dendrobium cruminatum $; \mathrm{B}=$ Hydnophytum formicarum $; \mathrm{C}=$ Dischidia nummularia $; \mathrm{D}=$ Hoya verticillata $\mathrm{E}=$ Pyrrosia piloselloides; $\mathrm{F}=$ Taeniophyllum glandulosum $; \mathrm{G}=$ Dendrobium $\mathrm{sp}$. 


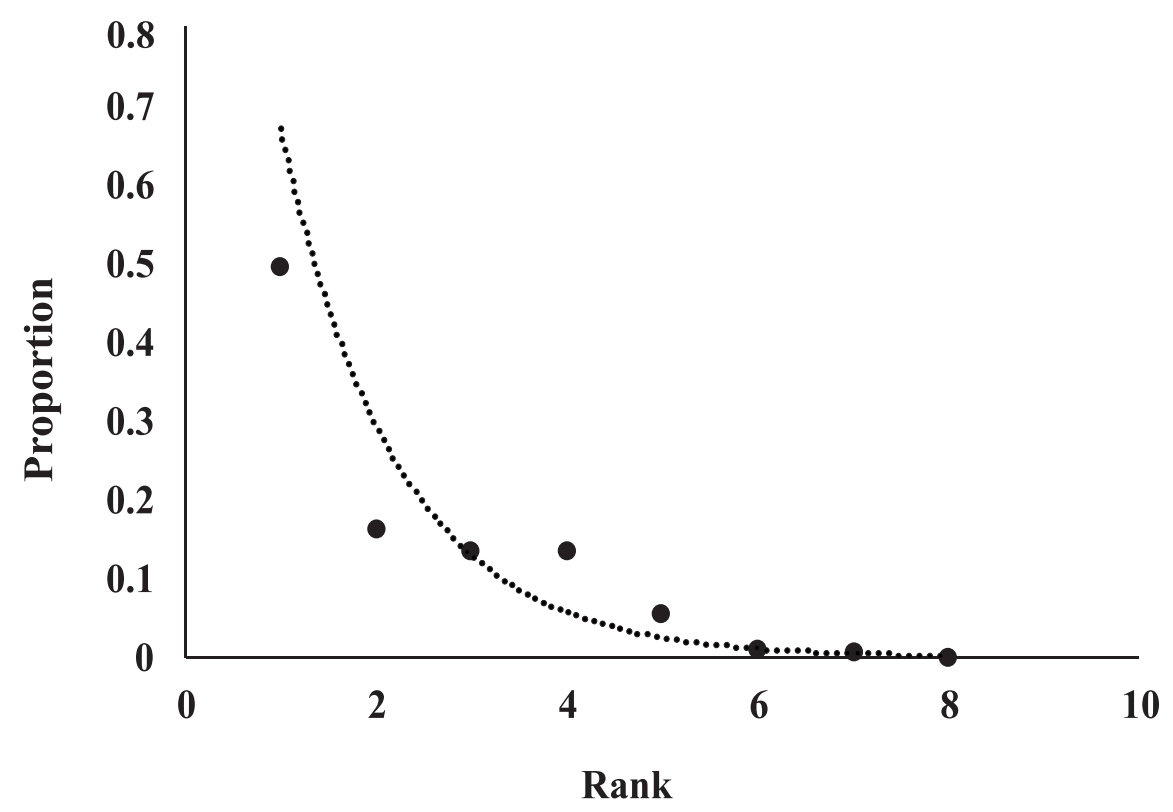

Figure 3 Rank-abundance of the 8 vascular epiphyte species in Pulau Telaga Tujuh, Terengganu, Malaysia

A total of 152 trees were occupied with vascular epiphytes (Table 2). These host trees are consisted of nine families, 11 genera and 13 species. Host trees that were occupied by the large number of epiphytes included Heritiera littoralis, Xylocarpus granatum and Ceriops zippeliana; meanwhile Pandanus fascicularis was the least occupied (Table 3). Cluster analysis grouped the host species into three major groups based on the composition of epiphytic species on the host trees (Fig. 4). Thirty percent of the vascular epiphytes of Planchonella obovata were similar to those of other host trees that shared at least $50 \%$ similar vascular epiphytes.
Epiphyte species richness is positively correlateed with the host's stem diameter (Hayasaka et al. 2012; Woods 2013; Wang et al. 2016; Sousa et al. 2017). However, the hosts with a high degree of epiphyte species richness were inland trees. This finding was confirmed in the clustering analysis where the third group comprised of trees that grow at mid-intertidal to landward zones. Another study highlighted the important role of inland trees as hosts to many epiphytic ferns in the mangroves of Thailand (Hayasaka et al. 2012). The trees in the inland zone tend to be mature and larger. This situation was also true in this study because the largest tree in the study plots, Xylocarpus granatum, has a $\mathrm{DBH}$ of $60 \mathrm{~cm}$.

Table 2 Host tree species with vascular epiphytes in Pulau Telaga Tujuh, Terengganu

\begin{tabular}{llc}
\hline Host tree & Family & $\begin{array}{c}\text { Number of individual } \\
\text { epiphytes }\end{array}$ \\
\hline Avicennia marina & Avicenniaceae & 3 \\
Bruguiera cylindrica & Rhizophoraceae & 7 \\
Bruguiera gymnorrbiza & Rhizophoraceae & 4 \\
Casuarina equisetifolia & Casuarinaceae & 5 \\
Ceriops tagal & Rhizophoraceae & 9 \\
Ceriops rippeliana & Rhizophoraceae & 30 \\
Excoecaria agallocha & Euphorbiaceae & 4 \\
Heritiera littoralis & Sterculiaceae & 34 \\
Hibiscus tiliaceus & Malvaceae & 3 \\
Pandanus fascicularis & Pandanaceae & 2 \\
Planchonella obovata & Sapotaceae & 3 \\
Rhizophora apiculata & Rhizophoraceae & 13 \\
Xylocarpus granatum & Meliaceae & 35 \\
\hline
\end{tabular}


Phorophytes characteristics such as bark structure can also influence the distribution of the epiphytes (Wyse \& Burns 2011; Sáyago et al. 2013; Wagner et al. 2015). Three phorophytes with the highest number of epiphytes were observed sharing a common trait, having a generally rough bark surface. Xylocarpus granatum possess a flaky and dippled bark, meanwhile Hiritiera littoralis and Ceriops decandra have fissured barks. These rough bark structures were able to trap much humus that was deposited as substrates for epiphytes (Nurfadilah 2015). Rough and fissured barks are able to accumulate litter and debris and to retain moisture from water trapped in between their crevices (Reyes $e t$ al. 2010; Zytynska et al. 2011). These structures will serve as microsites for epiphytes attachments aside from acting as water catchment and accumulating nutrients (Wagner et al. 2015). Rough surfaces also provide better mechanical support for attachments with better gripped surfaces for frictions, thereby logically explaining why plants species with smooth surface structure such as Nypa fruticans was not chosen as phorophytes even though they are quite numerous in Pulau Telaga Tujuh.

Table 3 Abundance of the vascular epiphytes on each host tree species in Pulau Telaga Tujuh, Terengganu

\begin{tabular}{|c|c|c|c|c|c|c|c|c|c|}
\hline \multirow{2}{*}{ Host tree species } & \multicolumn{8}{|c|}{ Number of individuals per epiphyte species on the host tree } & \multirow{2}{*}{ Total } \\
\hline & $\mathrm{DC}$ & $\mathrm{DN}$ & $\mathrm{HC}$ & $\mathrm{HV}$ & $\mathrm{HF}$ & PP & TG & DS & \\
\hline Avicennia marina & 5 & 2 & 0 & 0 & 9 & 0 & 0 & 0 & 16 \\
\hline Brugueira cylindrica & 0 & 1 & 0 & 0 & 6 & 15 & 2 & 0 & 24 \\
\hline Brugueira gymnorrbiza & 0 & 7 & 0 & 0 & 4 & 14 & 0 & 0 & 25 \\
\hline Casuarina equisetifolia & 0 & 0 & 0 & 0 & 10 & 6 & 0 & 0 & 16 \\
\hline Ceriops tagal & 0 & 3 & 1 & 3 & 3 & 2 & 7 & 0 & 19 \\
\hline Ceriops zippeliana & 1 & 22 & 7 & 0 & 52 & 14 & 53 & 0 & 149 \\
\hline Exoecaria agallocha & 0 & 26 & 0 & 0 & 10 & 11 & 0 & 0 & 47 \\
\hline Heritiera littoralis & 0 & 38 & 11 & 2 & 158 & 28 & 42 & 1 & 280 \\
\hline Hibiscus tiliaceus & 0 & 1 & 0 & 0 & 3 & 0 & 0 & 0 & 4 \\
\hline Pandanus fascicularis & 1 & 11 & 0 & 0 & 4 & 2 & 0 & 0 & 18 \\
\hline Pallaquim obovata & 0 & 0 & 2 & 0 & 7 & 0 & 0 & 0 & 9 \\
\hline Rhizophora apiculata & 1 & 9 & 2 & 0 & 23 & 25 & 20 & 0 & 80 \\
\hline Xylocarpus granatum & 0 & 30 & 28 & 0 & 173 & 10 & 1 & 0 & 242 \\
\hline
\end{tabular}

Notes: Epiphytes: $\mathrm{DC}=$ Dendrobium crumenatum $; \mathrm{DN}=$ Dischidianummularia $; \mathrm{HC}=$ Hoya coronaria $; \mathrm{HV}=$ Hoya verticillata; $\mathrm{HF}=$ Hydnophytum formicarum; $\mathrm{PP}=$ Pyrrosia piloselloides; TG = Taeniophyllum glandulosum; $\mathrm{DS}=$ Dendrobium sp.

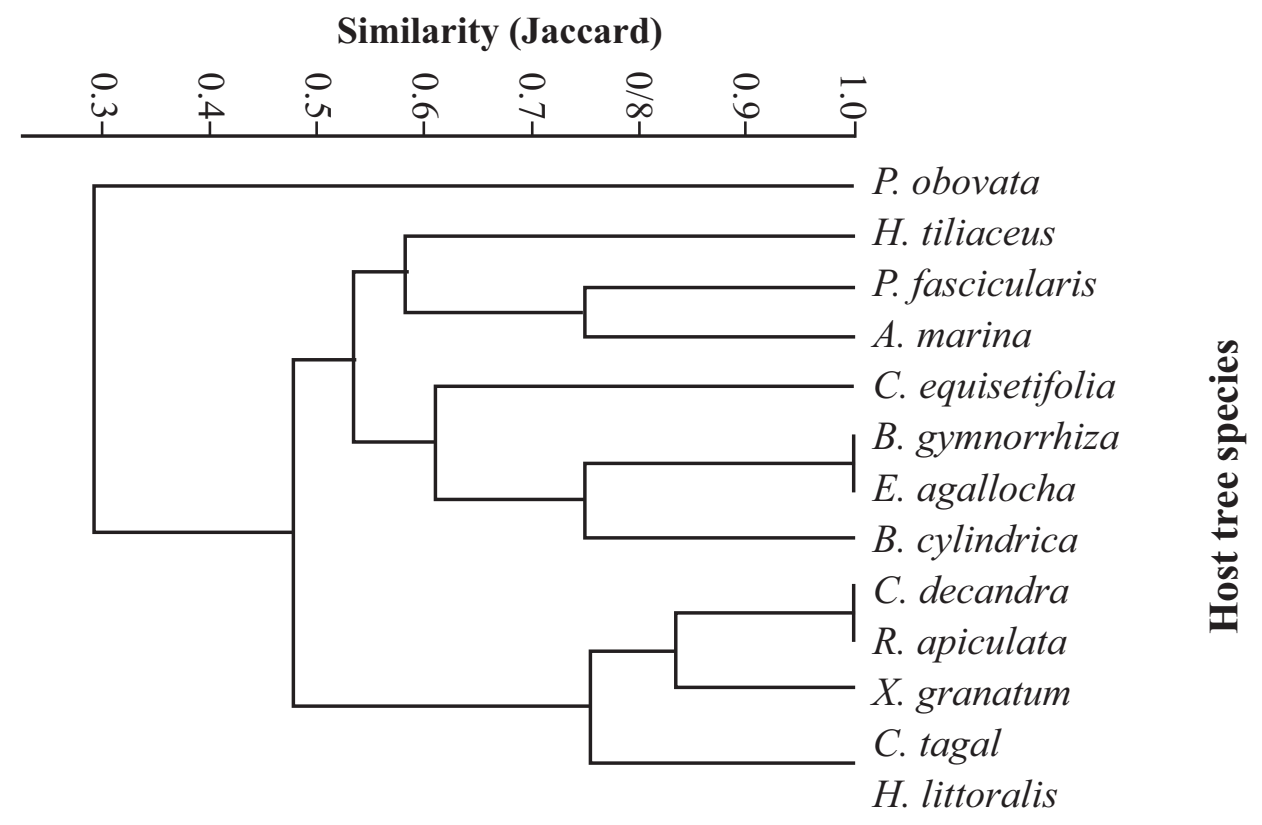

Figure 4 Cluster analysis according to the number of individuals per vascular epiphyte of each host tree species using the Jaccard similarity index 


\section{Vertical Distribution}

The "trunk" stratum was most frequently found to harbor epiphytes, followed by "canopy" and "basal" (Table 4). This type of vertical distribution was more or less consistent with many epiphytic studies (Quaresma \& Jardin 2014; Getaneh \& Gamo 2016; Mohamed et al. 2017). The preference of epiphytes in certain strata is influenced by their ability to adapt with various levels of photon flux density (PFD) and humidity (Benzing 1990). This acclimation process is prominent in stressful environment in mangrove forests as epiphytes are highly exposed to drought and salt spray. To adapt to drought conditions, the epiphytes in Pulau Telaga Tujuh probably undergo the CAM photosynthesis as physiological adaptation to survive in the stressful environment (Table 5). The relationship between CAM strategy and the epiphyte preferences for certain strata in this study is consistent with other observation that CAM species tend to clump in areas of higher light intensity and exposure (Zotz 2004).

Most CAM species are characterized by thick leaves, thereby reducing water loss (BarreraZambrano et al. 2014), which was also observed in all species found in Pulau Telaga Tujuh. Having schlerophyllous leaves also helps the epiphytes fight against the high salinity environment. Most epiphytes do not become halophyte to adapt with the saline environment (Zotz \& Reuter 2009). Hence, the epiphytes' low preference for sites at the basal area. Furthermore, permanent inundation of the basal region is not favourable for plant growth because a stable substrate is important for epiphyte establishment (Nieder et al. 2000; Hayasaka et al. 2012; Woods 2013). Similarly, a low concentration of epiphytes was observed at the lower strata of the host trees in our study.

Table 4 The presence of epiphytic plants on each stratum in Pulau Telaga Tujuh

\begin{tabular}{lccc}
\hline \multirow{2}{*}{ Vascular epiphyte species } & \multicolumn{2}{c}{ Number of individual epiphytes per stratum } \\
\cline { 2 - 4 } & Basal & Trunk & Canopy \\
\hline Dendrobium crumenatum & 6 & 2 & 0 \\
Dischidia nummularia & 22 & 82 & 66 \\
Hoya coronaria & 4 & 41 & 1 \\
Hoya verticillata & 0 & 4 & 151 \\
Hydnophytum formicarum & 22 & 289 & 22 \\
Pyrrosia piloselloides & 31 & 74 & 21 \\
Taeniophyllum glandulosum & 45 & 59 & 1 \\
Dendrobium sp. & 0 & 0 & 248 \\
\hline Total & 130 & 551 & \\
\hline
\end{tabular}

Table 5 Mode of photosynthesis for each vascular epiphytes in Pulau Telaga Tujuh extrapolated from Winter et al. (1983) and Hew \& Yong (2004)

\begin{tabular}{lc}
\hline \multicolumn{1}{c}{ Epiphyte species } & Mode of photosynthesis \\
\hline Dendrobium crumenatum & CAM \\
Dischidia nummularia & CAM \\
Hoya coronaria & CAM \\
Hoya verticillata & CAM \\
Hydnopbytum formicarum & Likely to vary between C3-CAM \\
Pyrrosia piloselloides & CAM \\
Taeniopbyllum glandulosum & CAM \\
Dendrobium sp. & More likely to be CAM than C3 \\
\hline
\end{tabular}




\section{CONCLUSION}

The diversity of vascular epiphytes in the mangrove forest of Pulau Telaga Tujuh was relatively low (Shannon index, $\mathrm{H}^{\prime}=1.43$ ) and the most abundant species was Hydnophytum formicarum. The vertical distribution of the epiphytes, being mostly situated on the trunk stratum, depicted the adaptations of these plants to stresses in the mangrove ecosystem, such as drought and salt spray. These findings can help support the conservation efforts directed towards this less appreciated plant group.

\section{ACKNOWLEDGEMENTS}

The authors would like to thank the Ministry of Education of Malaysia for funding this project under Niche Research Grant Scheme (Vot No. 53131/12). They would also like to thank Mohamad Razali Salam for helping them identify the epiphytes and host species.

\section{REFERENCES}

Awasthi OP, Sharma E, Palni LMS. 1995. Stemflow: A source of nutrients in some naturally growing epiphytic orchids of the Sikkim Himalaya. Ann Bot 75:5-11.

Barrera-Zambrano V, Lawson T, Olmos E, FernándezGarcia N, Borland A. 2014. Leaf anatomical traits which accomodate the facultative engagement of crassulacean acid metabolism in tropical trees of the genus Clusia. J Exp Bot 65:3513-23.

Benzing DH. 1990. Vascular epiphytes: General biology and related biota. Cambridge (UK): Cambridge University Press.

Cardelús CL, Mack MC 2010. The nutrient status of epiphytes and their host trees along an elevational gradient in Costa Rica. Plant Ecol 207:25-37.

Chomicki G, Renner SS. 2016. Obligate plant farming by a specialized ant. Nat Plants 2:16181.

Chuyong GB, Newbery DM, Songwe NC. 2004. Rainfall input, throughfall and stemflow of nutrients in a central African rain forest dominated by ectomycorrhizal trees. Biogeochemistry 67:73-91.

Coxson DS, Nadkarni NM. 1995. Ecological roles of epiphytes in nutrient cycles of forest ecosystems. In: Lowman NM, Nadkarni MD, editors. Forest Canopies (1st ed.). New York (USA): Academic Press. p. 495-543.
Dejean A, Durou S, Olmstedt I, Snellingt RR, Orivel J. 2003. Nest site selection by ants in a flooded Mexican mangrove, with special reference to the epiphytic orchid Myrmecophila christinae. J Trop Ecol 19(3):325-31.

Fürnkranz M, Wanek W, Richter A, Abell G, Rasche F, Sessitsch A. 2008. Nitrogen fixation by phyllosphere bacteria associated with higher plants and their colonizing epiphytes of a tropical lowland rainforest of Costa Rica. ISME J 2:561-70.

Getaneh ZA, Gamo FW. 2016. Vascular epiphytes in Doshke and Kurpaye: A comparative study, Gamo Gofa, Ethiopia. Int J Biodivers 2016:1-10.

Giesen W, Wulffraat S, Zieren M, Scholten L. 2007. Mangrove guidebook for Southeast Asia. Bangkok (TH): FAO and Wetlands International.

Hammer Ø, Harper DA, Ryan PD. 2001. PAST: Paleontological statistics software package for education and data analysis. Palaeontol Electron 4(1):1-9.

Hayasaka D, Kimura N, Fujiwara K, Thawatchai W, Nakamura T. 2012. Relationship between microenvironment of mangrove forests and epiphytic fern species richness along the Pan Yi River, Thailand. J Trop For Sci 24(2):265-74.

Hew CS, Yong JWH. 2004. The physiology of tropical orchids in relation to the industry. Singapore (SG): World Scientific Press.

Hietz P, Wanek W, Popp M. 1999. Stable isotopic composition of carbon and nitrogen and nitrogen content in vascular epiphytes along an altitudinal transect. Plant Cell Environ 22:1435-43.

Hietz P, Wanek W, Wania R, Nadkarni NM. 2002. Nitrogen-15 natural abundance in a montane cloud forest canopy as an indicator of nitrogen cycling and epiphyte nutrition. Oecologia 131:350-5.

Jamilah MS, Faridah M, Rohani S. 2015. Setiu: More than a wetland. In: Faridah M, Jamilah MS, Jarina MJ, Rohani S, editors. Setiu Wetlands: Species, Ecosystem and Livelihoods. Kuala Terengganu (MY): Penerbit Universiti Malaysia Terengganu. p. 87-100.

Japar Sidik B, Arshad A, Muta Harah Z, Normazilla M. 2001. Epiphytes of mangrove vegetation of Pulau Redang, Terengganu, Malaysia. In: Husain ML, Shahrom F, Law AT, Yunus K, Yaman ARG, editors. Proceeding of National Symposium on Marine Park and Terengganu Islands. p. 68-80.

Kaufmann E, Weissflog A, Hashim R, Maschwitz U. 2001. Ant-gardens on the giant bamboo, Gigantochloa scortechinii (Poaceae) in West-Malaysia. Insect Soc 48(2):125-33.

Kersten RA, Borgo M, Silva SM. 2009. Diversity and distribution of vascular epiphytes in an insular Brazilian coastal forest. Biotropica 32(3):385-96. 
Kiew R, Anthonysamy S. 1987. A comparative study of vascular epiphytes in three epiphyte rich habitats at Ulu Endau Johore Malaysia. Malay Nat J 41:30315.

Magurran AE, McGill BJ. 2011. Biological diversity: Frontiers in measurement and assessment. Oxford (UK): Oxford University Press.

Mohamed E, Kebebew M, Awas T. 2017. Diversity of vascular epiphytes in Wondo Genet natural forest, Southern, Ethiopia. Int Res J Biol Sci 6(2):5-15.

Nadkarni NM, Matelson TJ. 1989. Bird use of epiphyte resources in Neotropical trees. Condor 91(4):891907.

Nadkarni NM, Schaefes D, Matelson MJ, Solano R. 2004. Biomass and nutrient pools of canopy and terrestrial components in a primary and a secondary montane cloud forest, Costa Rica. For Ecol Manag 198:223-36.

Nieder J, Engwald S, Klawun M, Barthlott W. 2000. Spatial distribution of vascular epiphytes (including hemiepiphytes) in a lowland Amazonian rain forest (Surumoni crane plot) of Southern Venezuela. Biotropica 32(3):385-96.

Nurfadilah S. 2015. Diversity of epiphytic orchids and host trees (phorophytes) in secondary forest of Coban Trisula, Malang Regency, East Java. BIOTROPIA 22(2):120-8.

Quaresma A, Jardin M. 2014. Floristic composition and spatial distribution of vascular epiphytes in the restingas of Maracanã, Brazil. Acta Bot Bras 28(1):68-75.

Reyes F, Silvana Z, Espinosa A, Marysol A. 2010. Biochemical properties in vascular epiphytes substrate from a temperate forest of Chile. J Soil Sci Plant Nutr 110(2):126-38.

Rohani S, Abdul Shukor Y, Kamaruzzaman MF, Mohd Razali S. 2017. Distribution and host identification of epiphytic plant, Hydnophytum formicarum Jack, in Pulau Telaga Tujuh, Setiu, Terengganu. J Sustain Sci Manag 12(2):128-34.

Sáyago R, Lopezaraiza-Mikel M, Quesada M, ÁlvarezAñorve MY, Cascante-Marín A, Bastida J M. 2013. Evaluating factors that predict the structure of a commensalistic epiphyte-phorophyte network. P Roy Soc B-Biol Sci 280:1-9.

Silvera K, Neubig KM, Whitten WM, Williams NH, Winter K, Cushman JC. 2010. Evolution along the crassulacean acid metabolism continuum. Funct Plant Biol 37:995-1010.

Sousa MM, Colpo KD. 2017. Diversity and distribution of epiphytic bromeliads in a Brazilian subtropical mangrove. An Acad Bras Ciên 89(2):1085-93.

Turner IM. 1995. A catalogue of the vascular plants of Malaya. Gard Bull (Singapore) 47(2):347-655.

Wagner K, Mendieta-Leiva G, Zotz G. 2015. Host specificity in vascular epiphytes: A review of methodology, empirical evidence and potential mechanisms. AoB Plants 7:plu092.

Wang X, Long W, Schamp BS, Yang X, Kang Y, Xie Z, Xiong M. 2016. Vascular epiphyte diversity differs with host crown zone and diameter, but not orientation in a tropical cloud forest. PLoS One 11(7):1-13.

Winter K, Wallace BJ, Stocker GC, Roksandic Z. 1983. Crassulacean acid metabolism in Australian vascular epiphytes and some related species. Oecologia 57:129-41.

Woods CL, Cardelús CL, Dewalt SJ. 2015. Microhabitat associations of vascular epiphytes in a wet tropical forest canopy. J Ecol 103(2):421-30.

Woods CL. 2013. Factors influencing the distribution and structure of tropical vascular epiphyte communities at multiple scales [Dissertation]. Retrieved from Clemson University, South Carolina.

Wyse SV, Burns BR. 2011. Do host bark traits influence trunk epiphyte communities? New Zeal J Ecol 35(3):296-301.

Zotz G. 2004. How prevalent is crassulacean acid metabolism among vascular epiphytes? Oecologia 138:184-92.

Zotz G, Reuter N. 2009. The effect of exposure to sea water on germination and vegetative growth of an epiphytic bromeliad. J Trop Ecol 25(3):311-9.

Zotz G. 2013. The systematic distribution of vascular epiphytes-a critical update. Bot J Linn Soc 171(3):453-81.

Zotz G. 2016. Plants on plants - The biology of vascular epiphytes. Basel $(\mathrm{CH})$ : Springer Nature.

Zytynska SE, Fay MF, Penney D, Preziosi RF. 2011. Genetic variation in a tropical tree species influences the associated epiphytic plant and invertebrate communities in a complex forest ecosystem. Philos T R Soc B 366:1329-36. 